\title{
Petroleum Potential Prospects of the Central Part of Krasnoyarsk Krai
}

\author{
Viacheslav G. Vasilev* \\ Siberian Federal University \\ 79 Svobodny, Krasnoyarsk, 660041, Russia
}

Received 12.07.2016, received in revised form 14.09.2016, accepted 11.11.2016

Proposed a new interpretation of trapps effect on the petroleum potential of Tunguska syncline (North and South Tunguska oil-gas region). Is proved: spread of primary salt-generating basin on whole territory of Siberian platform, the two-phase nature of magma intrusion into sedimentary cover, formation of regional high-capacity reservoirs in place superseded salts.

Keywords: Tunguska synclime, traps, magma plume, algal reefs, rock salt.

Citation: Vasilev V.G. Petroleum potential prospects of the central part of Krasnoyarsk krai, J. Sib. Fed. Univ. Eng. technol., 2016, 9(8), 1349-1352. DOI: 10.17516/1999-494X-2016-9-8-1349-1352.

\section{Перспективы нефтегазоносности центральной части Красноярского края}

В.Г. Васильев

Сибирский федеральный университет Россия, 660041, Красноярск, пр.Свободный, 79

Предложена новая трактовка влияния траппового магматизма на нефтегазоносность Тунгусскойсинеклизы (Северо-и Южно-Тунгусскаянефтегазоносныеобласти). Доказывается распространение первичного солеродного бассейна на всю территорию Сибирской платформы, двухфазовый характер внедрения магмы в осадочный чехол, образование региональных высокоемких коллекторских горизонтов на месте вытесненных солей.

Ключевые слова: Тунгусская синеклиза, траппы, магматический плюм, водорослевые рифы, каменные соли.

Исторически сложилось так, что геологоразведочные работы на нефть и газ в центральной части территории Красноярского края, куда мы относим Южно- и Северо-Тунгусскую нефтегазоносные области, выполнены в значительно меньших объемах относительно остальной части региона. Основными причинами сложившейся ситуации явились: во-первых, труднодо-

(c) Siberian Federal University. All rights reserved

* Corresponding author E-mail address: vas211219@mail.ru 
ступность территории с горно-таежным рельефом местности и суровым климатом, во-вторых, сложное геологическое строение, в-третьих, неясные перспективы нефтегазоносности, связанные с влиянием траппового магматизма на сохранность месторождений углеводородов. Открытие в отложениях нижнего кембрия Южно-Тунгусской НГО Таначинского, Моктаконского и Нижнетунгусского месторождений углеводородов установило сам факт наличия потенциала нефтегазообразования в рассматриваемом районе.

В истории развития Земли трапповый магматизм проявлялся неоднократно и, на текущий момент, в мире хорошо известны и изучены свыше 15 крупных магматических провинций. Наиболее значимые после Сибирского произошли: в юрское время с образованием плато Карру-Феррар-Тассманское (плюм Буве), в меловое - плато Парана-Этендека (плюм Тристан), плато Земля Мери Берд (Австралийско-Новозеландский рифтинг) и Мадагаскарское плато (плюм Марион), в палеогеновое - плато Декан (плюм Реюньон). Однако ни одно из перечисленных явлений не оказало такого влияния на историю развития Земли, как Восточно-Сибирское на рубеже палеозоя и мезозоя. Излияние магмы послужило причиной массового вымирания фауны на планете, погибло 96 \% морских животных и около 70 \% наземных. Общий объем пермотриасовых траппов Сибири составляет $130 * 10^{6}$ км$^{3}$, из них на долю Тунгусской синеклизы пришлось $33^{*} 10^{6}$ км$^{3}$. Поскольку источник (мантия) и процесс внедрения магмы (плюмы и рифтогенез) одинаковы для всех, причину масштабности сибирского траппового магматизма следует искать непосредственно в геологическом строении территории. Выясним, почему под Сибирской платформой смог накопиться такой объем магматического материала.

В геологическом строении Лено-Тунгусской НГП принимают участие фундамент и осадочный чехол. Кристаллический фундамент выходит на дневную поверхность на Анабарском щите и вскрыт рядом скважин. Осадочный чехол представлен преимущественно карбонатным рифеем, карбонатно-терригеным вендом, палеозойскими отложениями с карбонатногалогенным нижним кембрием в основании и пермскими угленосными отложениями в верхней части, непосредственно выше залегает триасовая туфолавовая толща трапповой формации. Особенностями геологического строения осадочного чехла являются: во-первых, резко различное насыщение интрузиями нижней галогенной части разреза и верхней бессолевой и, вовторых, выдержанное по простиранию разграничение соленосного и несоленосного разрезов. Первое выражается в преобладании относительно выдержанных по мощностям и местам внедрений силлов над секущими интрузиями в карбонатно-галогенном кембрии с преобладанием секущих не выдержанных по мощностям и местам внедрения в вышележащих отложениях. Второе - в наличии субпараллельной границе Тунгусской синеклизе узкой полосы, отождествляемой с водорослевыми рифогенными отложениями, ограничивающей солеродный бассейн. Причем, по обе стороны рифового барьера карбонатные горизонты кембрия достаточно уверенно сопоставимы, приуроченность интрузивных силлов близка, а на уровне солей в бессолевом разрезе выделяются пространственно выдержанные коллекторские горизонты. Далее, по геодинамической модели образования сибирских траппов из осадочного чехла исчезла толща пород мощностью около 2 км. Авторы объясняют это выгоранием углей, но в колонковых скважинах со 100\%-ным отбором и выносом керна изменение угленосных отложений не наблюдается и породы «горелики» отсутствуют, а туфолавовая толща триаса залегает на субгоризонтальной выровненной поверхности палеозоя $[1,2]$. 
Все противоречия снимаются, если предположить, что на момент внедрения магмы в осадочный чехол солеродный бассейн распространялся на всю Сибирскую платформу. В этом случае при продвижении магмы (температура в верхней части плюма $\left.1600{ }^{\circ} \mathrm{C}\right)$ к поверхности отложения солей постепенно переходили в расплав (температура плавления 600-900 ${ }^{\circ} \mathrm{C}$, температура кипения 1400-1500 드 [3]. Образовывалась сверхпрочная толща из пластичных и твердых пластов, способная выдержать взрывной характер внедрения и удерживать большой объем магмы. Под действием горного давления вышележащих пород (средняя плотность 2,7

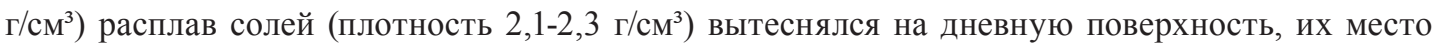
занимала магма (плотность базальтовой магмы 2,6-2,8 г/см³) [4] с образованием промежуточного магматического очага. Образование соленосных отложений с проявлением магматизма в соседних регионах связывает между собой М.К. Калинко [5], выдвигая гипотезу гипергенновулканогенно-осадочного образования полирегиональных и региональных соленосных толщ.

В этом случае среднепермские соли Русской платформы являются следствием перераспределения кембрийских солей Сибири, а продолжительность формирования промежуточного магматического очага определяется периодом средняя пермь - триас. Время достаточное, чтобы прогреть весь осадочный чехол до 1200 ㄷ․ После вытеснения солей из разреза над магматическим очагом оказалась толща твердых пород, неспособная компенсировать взрывное внедрение магмы. Магма стала прорываться на дневную поверхность в местах наименьшего сопротивления, образуя мелкие промежуточные очаги и не выдержанные по мощности силы, дайки, трубки взрыва. По мере продвижения к поверхности магма достигала глубин с давлением насыщения летучими компонентами, что приводило к пульсациям и образованиям туфов. Аналогичный процесс наблюдается при испытании нефтяных скважин при АНПД с высоким газовым фактором. Излившись на дневную поверхность, лава создала: во-первых, многослойный термоизоляционный сэндвич-пакет из туфов и базальтов и, во-вторых, дополнительное избыточное горное давление на остаток магмы в промежуточном кембрийском очаге. Следствием последнего стало выдавливание магмы на периферию и за пределы Тунгусской синеклизы. Подтверждением являются определения возраста кембрийских силлов, которые моложе возраста платобазальтов. Возможно, что внедрение интрузий в кембрийские соленосные отложения к югу от Тунгусской синеклизы происходило горизонтально. Обращает на себя внимание также повсеместное положение пластовой интрузии строго посредине песчаников байкитской свиты нижнего ордовика на одноименной антеклизе, что трудно объяснить без факта гидроразрыва пласта.

В пользу предлагаемой трактовки может служить также следующее. Характер осадкообразования карбонатных отложений, их фациальная изменчивость не позволяют предполагать образования региональных высокоемких коллекторских горизонтов. Отсюда «костинские» коллекторы по своей природе вторичны. Рифы в любой модификации образуются внутри карбонатных формаций и никогда не ограничивают солеродные бассейны. Достаточно обратить внимание на кольцевые атоллы, где соленость воды внутри и за пределами рифа одинакова. Однако, сказанное не отвергает наличия в регионе самих рифов [6].

Влияние описываемого процесса на нефтегазоносность Тунгусской синеклизы огромно и неоднозначно. Отрицательное - полное уничтожение имеющихся месторождений нефти; повсеместно в скважинах наблюдается высокое (до 25 \%) содержание в породах органического 
углерода в виде антраксолитов при отсутствии подвижных битумоидов (редко выше 0,005 \%) и усложнение геологического строения. Положительными моментами являются: во-первых, образование крупнейшего единого артезианского бассейна с наличием в водах сложных органических соединений, во-вторых, образование региональных высокоемких коллекторских горизонтов, в-третьих, образование покрышек за счет засолонения пластов горячими рассолами, в-четвертых, вероятное отсутствие в кембрии центральной части синеклизы интрузий, в-пятых, рассеивание сопутствующих магматизму платиноидов и других металлов по артезианскому бассейну с последующим участием их в каталитических процессах преобразования углеводородов с образованием ароматических нефтей [7], в-шестых, наряду с имеющимися до внедрения ловушками образование новых за счет засолонения коллекторов по восстанию пластов и тектонического экранирования.

\section{Список литературы}

[1] Соболев А.В., Соболев С.В., Кузьмин Д.В., Малич К.Н., Петрунин А.Г. Механизм образования Сибирских меймечитов и природа их связи с траппами и кимберлитами. Геология и геофизика, 2009б, 50(12), 1291-133 [Sobolev A.V, Sobolev S.V, Kuzmin D.V., Malich K.N., Petrunin A.G. The mechanism of formation of Siberian meimechites and the nature of their connection with the traps and kimberlites. Geology and Geophysics, 2009b, 50(12), 1291-133 (in Russian)]

[2] Соболев А.В., Криволуцкая Н.А., Кузьмин Д.В. Петрология родоначальных расплавов и мантийных источников магм сибирской трапповой провинции. Петрология, 2009a, 17, 3, $276-$ 310 [Sobolev A.V, Krivolutskaia N.A.,, Kuzmin D.V. Petrology of the parental melts and mantle sources of magmas of the Siberian trap province Petrology, 2009a, 17, 3, 276-310 (in Russian)]

[3] Кобранова В.Н. Физические свойства горных пород. М.: Гостоптехиздат, 1962. 376 с. [Kobranova V.N. Physical properties of rocks. Moscow, Gostoptekhizdat, 1962. 376 p. (in Russian)]

[4] Справочник физических констант горных пород. М.: Мир, 1969. 541 с. [Handbook of physical constants of rocks. Moscow, Mir, 1969. 541 p. (in Russian)]

[5] Калинко М.К. Соленакопление, образование соляных структур и их влияние на нефтегазоносность. М.: Недра, 1973. 130 с. [Kalinko M.K. Salt accumulation, the formation of salt structures and their impact on petroleum potential. Moscow, Nedra, 1973. 130 p. (in Russian)]

[6] Уилсон Дж.Л. Карбонатные фации в геологической истории. М.: Наука, 1980. 462 с. [Wilson J. L. . Carbonate Facies in Geologic History. Moscow, Nauka, 1980. 462 p. (in Russian)]

[7] Битнер А.К. Особенности геологии и геохимии триады «нефть-конденсат-газ» залежей Южно-Тунгусской нефтегазоносной области и перспективы их комплексного использования. Новосибирск: СНИИГГиМС, 2010. 112 с. [Bitner А.К. Features of the Geology and Geochemistry of the triad «oil-condensate-gas» deposits of South Tunguska oil-gas region and prospects for their integrated use. Novosibirsk, SNIIGGiMS, 2010. 112 p. (in Russian)] 